\title{
Dědečkové vs. babičky. Prarodičovství v kontextu aktivního stárnutíi
}

\section{Grandfathers vs. Grandmothers: Grandparenthood in the Context of Active Ageing}

\author{
Nela Patschová
}

\begin{abstract}
This article discusses the theme of grandparenthood in comparison with grandmotherhood. In the Czech Republic there is a lack of research on grandfathers, and international researchers started to focus on grandfathers only recently. There is no consistent theoretical conception of grandparenthood so this article focuses on different contexts of grandparenthood like gender stereotypes, demographic and social changes, and the overloaded role of ageing individuals. It also introduces factors influencing the care for children of grandfathers. An analysis of SHARE data ${ }^{2}$ is used to examine the influence of those factors on the frequency of care provided to grandchildren by their grandparents and compares grandfathers and grandmothers. The analysis confirms the influence of marital status, age, health, economic activity and the number of grandchildren. The article also provides recommendations for further research of grandfatherhood and its role within the family. The conclusions offered here are part of a broader research project focused on grandfatherhood.
\end{abstract}

KEY WORDS Grandfatherhood, grandmotherhood, grandparenthood, care for grandchildren, ageing, gender

Sociální studia. Katedra sociologie FSS MU, 3/2014. S. 51-73. ISSN 1214-813X.

1 Tato stat' vznikla díky finanční podpoře projektu Specifického výzkumu Masarykovy univerzity „Manželství, domov a rodičovské dráhy“ (MUNI/A/0914/2013).

2 Tento článek využívá data ze 4. vlny SHARE, vydání 1.1.1, z 28. března 2013 (DOI: 10.6103/ SHARE.w4.111) nebo 1. a 2. vlny SHARE, vydání 2.6.0, z 29. listopadu 2013 (DOI: 10.6103/ SHARE.w1.260 and 10.6103/SHARE.w2.260) nebo SHARELIFE, vydání 1, z 24. listopadu 2010 (DOI: 10.6103/SHARE.w3.100). Sběr dat SHARE byl primárně financován Evropskou komisí skrze 5. rámcový program (projekt QLK6-CT-2001-00360 v tematickém programu Quality of Life), skrze 6. rámcový program (projekty SHARE-I3, RII-CT-2006-062193, COMPARE, CIT5- CT-2005-028857, a SHARELIFE, CIT4-CT-2006-028812) a skrze 7. rámcový program (SHARE-PREP, N 211909, SHARE-LEAP, N²27822 a SHARE M4, N²61982). S povděkem přiznáváme také finanční podporu z U.S. National Institute on Aging (U01 AG09740-13S2, P01 AG005842, P01 AG08291, P30 AG12815, R21 AG025169, Y1-AG-4553-01, IAG BSR06-11 a OGHA 04-064), německého Ministerstva školství a výzkumu i různých národních zdrojů (úplný seznam financujících institucí viz www.share-project.org). 
Význam výzkumu prarodičovství roste s demografickými a sociálními změnami. Počet seniorů se zvyšuje a je třeba zabývat se jejich místem ve společnosti (Hasmanová Marhánková 2010, 2013; Thompson a Whearty 2004; Wilton a Davey 2006), které by jim po odchodu do důchodu přináleželo. To zřejmě zamýšleli i tvůrci konceptu aktivního stárnutí, který stárnoucí občany podporuje v odhodlání zůstat aktivními. At’ už ve formě participace na trhu práce, zapojování se do volnočasových aktivit, docházení do seniorských center anebo zapojování se do rodinného života právě formou prarodičovství, tedy péče o vnoučata (Hasmanová Marhánková 2010, 2013; Boudiny 2012).

Dědečkům a jejich proživání dědečkovské role byla v dosavadních výzkumech věnována jen velmi malá pozornost. Většinou se studie zaměřovaly spíše na ženy a babičky jako primární poskytovatele mezigenerační péče (Tarrant 2012; Bates 2009; Wilton a Davey 2006; Fingerman 2004; Bates a Taylor 2003; Mann 2007; Connell 2005). Většina literatury na téma prarodičovství pochází z USA a Velké Británie (Mann a Leeson 2010; Mann 2007; Wilton a Davey 2006; Fingerman 2004), takže jejich zjištění musí být aplikovány na české prostředí s obezřetností a s ohledem na sociokulturní rozdíly. Přesto v tomto článku pracuji především se zahraničními studiemi a to kvůli nedostatku českých článků na dané téma. Platnost jejich zjištění pro české dědečky a babičky je tedy třeba otestovat.

Mým cílem je zaměřit se na české dědečky, kteří naplňují svou dědečkovskou roli, tedy hlídají svá vnoučata alespoň jednou do měsíce, a srovnat je s babičkami. Hodlám také srovnat dědečky, kteří vnoučata nehlídají vůbec a kteří o ně pečují alespoň téměř každý týden.

Výsledkem této studie bude zjištění, zda se babičky a dědečkové nějak liší, především ve frekvenci péče o vnoučata, které faktory na ni mají vliv a zda se tyto faktory nějak liší podle genderu.

\section{Proč jsou dědečci ve výzkumu prarodičovství tolik zanedbáváni?}

Podle Batese (2009) a Batese a Taylora (2003) je jedním z důvodů zanedbání mužů ve výzkumu prarodičovství absence teoretického a konceptuálního základu, který by výzkumníkům a vědcům umožnil vystavět konzistentní teorii o dědečcích a jejich prožívání dědečkovské role.

Podíl na této situaci má zřejmě také představa mužů jako těch, co se méně než ženy účastní výzkumů a nejsou tak ochotní mluvit o rodinných záležitostech (CunninghamBurley 1984; Waldrop a Weber 2001). Waldrop a Weber (2001) přisuzují podreprezentovanost dědečků ve výzkumech i vyšší naději dožití žen. Řada autorů, například Ando (2005), Somary a Stricker (1998), Albert (1954), Reitzes a Mutran (2004), Aronson (1990, 1992), Wilton a Davey (2006) a Gradman (1994), hovoří o tom, že negativní roli hraje i stereotypní chápání mužů jako živitelů rodiny a spojování jejich života spíše s placenou prací než s péčí o děti, vnoučata a rodinu.

Někteří autoři (Gutman 1994; Gradman 1994) však uvádí, že dochází k oslabení těchto stereotypů, což se mimo jiné projevuje i větším počtem mužů pečujících o děti, vnoučata či jiné členy rodiny. Jiní jsou však toho názoru, že přestože dochází k určitým změnám ve společnosti, stereotypní představy o mužích zůstávají normou, podle níž muži posuzují sami sebe a jsou podle nich také posuzováni (Thompson a Whearty 2004; Emslie, Hunt a O’Brien 2004). 
To pak může mít za následek, že ačkoliv se už muži nebojí věnovat se i nemaskulinním aktivitám (Wilton a Davey 2006), jakými je třeba péče o vnoučata, nechtějí o těchto aktivitách hovořit, nezdůrazňují je anebo o jejich frekvenci či intenzitě sdělují ostatním jen částečnou pravdu. To vše může značně zkreslovat zjištění dosavadních výzkumů.

Podle Manna, Khana a Leesona (2009) a Tarrant (2010) se však zdá, že muži se s postupem času méně obávají projevit i své pečující sklony a ženy si zase mohou dovolit naplnit svůj volný čas v důchodu i jinými aktivitami než jen péčí o druhé.

\section{Prarodičovství jako jedna z mnoha aktivit seniorů}

Prarodičovství se s postupujícím časem značně proměnilo. Nejen, že dnes už takřka každý pozná alespoň jednoho svého prarodiče vlivem zvyšující se naděje dožití a klesající úmrtnosti, ale také délka prarodičovské role se tak prodlužuje a vztahy mezi vnoučaty a prarodiči přetrvávají často až do rané dospělosti dětí. Díky lepšímu zdravotnímu stavu, finanční situaci seniorů a rozvoji technologií se mohou prarodiče věnovat vnoučatům častěji a intenzivněji, a to s menšími fyzickými, geografickými či jinými omezeními (Uhlenberg 2005; Ando 2005; Millward 1998; Tarrant 2010).

Na prarodičovství má vliv podle Millward (1998) a Tarrant (2010) i snižující se porodnost, která vede $\mathrm{k}$ tomu, že se prarodiče dříve zbavují svých rodičovských povinností, a tím dříve se mohou věnovat péči o vnoučata a jiným aktivitám (Cherlin a Furstenberg 1986).

Ačkoliv prarodičovská role bývá pro mnohé prarodiče primární mezigenerační rolí, rozhodně není rolí jedinou. Jak upozorňují někteří zahraniční autoři (Tarrant 2012; Mann et al. 2009), není výjimkou, že se s prarodičovstvím prolíná participace na trhu práce (doba odchodu do důchodu je neustále oddalována), péče o vlastní staré rodiče, kteří si už sami nevystačí (příčinou je zvyšující se naděje dožití), nebo také péče o vlastní děti (vlivem stále častějších pozdních těhotenství nebo přijetí dětí z dalších manželství za své). Snadno se tedy může stát, že prarodiče pocit’ují přetížení rolí.

Přetížení rolí Duxbury, Lyons, Higgins (2008) definují jako pocit nedostatku času na aktivity, které dělat chceme, musíme anebo bychom měli. Znamená to cítit se ve spěchu a v časovém tlaku, fyzicky a emočně vyčerpaný a vyprahlý, mít pocit, že na sebe nemám dost času. Koncept přetíženosti rolí by si jistě zasloužil více pozornosti nejen v př́padě střední generace, ale i seniorů, nad nimiž se vznáší neustálý požadavek aktivity ve stárí a často také očekávání týkající se péče o vnoučata či stárnoucí rodiče, zatímco oni by rádi prožívali důchod takovým způsobem, jaký si vysnili.

Snaha o udržení určité svobody a nastavení hranic prarodičovské role se zřejmě projevuje i tím, že korezidence prarodičů s jejich dětmi a vnoučaty nejsou v západním světě nijak časté (Kohli 1998; Silverstein et al. 2006). Kohli (1998) uvádí, že asi 9\% osob ve věku 70 až 85 let žije v jedné domácnosti se svými dětmi, 27\% dětí ale žije ve stejném domě jako jejich rodiče, $45 \%$ dětí v sousedství rodičů a 9 z 10 dětí pak žije v dojezdové vzdálenosti dvou hodin od svých rodičů. Tyto údaje tedy napovídají, že ačkoliv prarodiče žijí blízko svých dětí, nežijí s nimi př́liš často $\mathrm{v}$ jedné domácnosti, a tedy si obě strany chtějí udržet určitou soběstačnost (Tarrant 2010; Silverstein et al. 2006), což je zcela v souladu s imperativem aktivního stárnutí, kterému se budu věnovat v následujícím oddílu. 


\section{Péče o vnoučata či jiné rodinné príslušníky jako jedna z dimenzí aktivního stárnutí}

Stáŕí bylo dlouho chápáno jako období úpadku těla i mysli (Hasmanová Marhánková 2013; Higgs et al. 2009). Nyní se však stárnutí dostává mnohem větší pozornosti od společnosti obecně, samotných stárnoucích jednotlivců i státu (Phillipson a Powell 2004; Boudiny 2012; Rowe a Kahn 1998). Aktivní život ve stáří se podle Hasmanové Marhánkové (2013) stává nejen otevřenou možností, ale dokonce i povinností, což může vést k utváření normativních představ o stáří (Andrews 1999; Moody 2001).

Normativitu aktivního stárnutí posiluje fakt, že jeho koncept je součástí mnoha státních i mezinárodních dokumentů. To pak může mít vliv na prožívání života ve stáří i prarodičovství jako jednu z dimenzí aktivního stárnutí (Phillipson a Powell 2004).

Ačkoliv koncept aktivního stárnutí postrádá konzistentní formulaci, obvykle jeho definice odkazují k podobným charakteristikám. Stáří již není vnímáno jako pasivní životní období bez možnosti sebenaplnění a postrádající role v rodině i společnosti (Rowe a Kahn 1998; Jones et al. 2008). Nyní je stáří podle Hasmanové Marhánkové považováno za období sebenaplnění, vykonávání koníčků a prŕiležitosti „dělat, co chceme, ale nemuset dělat nic“ (Hasmanová Marhánková 2013: 65).

Weiss a Bass (2002) jsou toho názoru, že tato svoboda se stává nejen svobodou od něčeho (pracovních či rodinných povinností), ale rovněž svobodou k něčemu (novým koníčkům, cestování, vzdělávání...). Hasmanová Marhánková (2013) jde ještě dále a tvrdí na základě výzkumu českých seniorů docházejících do seniorských center, že aktivita je jasně vymezená imperativem ,muset něco dělat", který ovlivňuje i percepce vlastního stárnutí. To může klást velké požadavky na prarodiče, zejména dědečky, kteří přichází o placenou práci, jež je podle mnoha autorů klíčovým naplněním života mužů (Wilton a Davey 2006; Gradman 1994), ztrácí tak svou hlavní roli v rámci rodiny a snaží se najít novou.

Pečující role (at’ už o vnoučata či stárnoucí rodiče) jsou však přisuzovány spíše ženám než mužům. To podporují data z mnoha zahraničních výzkumů (Ando 2005; Somary a Stricker 1998; Albrecht 1954), avšak v českém prostředí je třeba tato tvrzení ověřit.

Podle Katze (2000) je aktivita často úzce spojována s co nejdelší participací na trhu práce, celoživotním vzděláváním a aktivním životním stylem a stává se klíčovým aspektem současné představy dobrého stáří. V tomto chápání však můžeme poněkud postrádat dimenzi péče o př́buzné, např. právě o vnoučata. Tu už obsahuje definice $\mathrm{OECD}^{3}$ (citováno in Rabušic, Vidovićová 2003), v níž je zahrnuta i individuální volba, kdy si aktivně stárnoucí jedinci mohou vybrat, jak budou trávit svůj volný čas - jestli dalším vzděláváním, prací, anebo právě péčí o rodinné př́íslušníky.

Hasmanová Marhánková (2013) ve své studii z českých seniorských center zjistila, že hlídání vnoučat je sice důležité pro životy prarodičů, ale rozhodně není centrální ani automatické. Prarodičovská role je podle ní často vymezována v kontextu vlastního životního stylu a vlastních zájmů prarodiče. Někteří senioři v její studii také poukazovali na přetížení role, kdy měli pocit, že kvůli př́lišs velkému zapojení do péče o vnoučata nemají možnost trávit

3 Organization for Economic Co-operation and Development. 
svůj volný čas, jak by chtěli. V tomto prŕípadě je však třeba myslet na to, že senioři, kteří dochází do seniorských center, jsou poměrně specifickou skupinou.

Je třeba zajímat se o rozdíly mezi prarodiči s různou mírou aktivity a jejich postoji k péči o vnoučata, protože - jak upozorňují mnozí zahraniční autoři (Gilleard a Higgs 2000; Laslett 1991; Millward 1998; Tarrant 2010; Neugarten a Weinstein 1964; Ando 2005) - život v důchodu, proživání staří i prarodičovství je značně heterogenní a dá se hovořit o různých životních stylech a o různých stylech prarodičovství. Tuto heterogenitu můžeme jistě očekávat i mezi českými seniory a prarodiči.

Podle Lasletta (1991) a Katze (2000) je to právě možnost zvolit si z mnoha způsobů prožívání stáŕí, co seniorům umožňuje po odchodu do důchodu budování identity na nových základech a ne pouze ve vztahu $\mathrm{k}$ absenci ekonomické aktivity.

Dnes tedy může být hledání nových rolí a budování nových identit stárnoucích mužů snazší a to především díky tomu, že seniorům byly nabídnuty zásady aktivního stárnutí jako nový směr v jejich životě. Ženy se už nestydí ŕíct nahlas, že jediným posláním jejich života není péče o ostatní, a muži mladších věkových kohort se postupně odhodlávají zapojit se do aktivit, které dř́ve byly přisuzovány spíše ženám ${ }^{4}$ (Mann, Khan a Leeson 2009; Wilton a Davey 2006).

\section{Péče o vnoučata jako zdroj „nové“ diskriminace seniorů}

Idylická představa důchodového věku je mimo jiné i výsledkem současné modernizované a individualizované společnosti (Rubinstein 2002; Beck a Beck-Gernsheim 1995; Sýkorová 2007).

Prarodičovství je však $\mathrm{v}$ určité míre poněkud $\mathrm{v}$ kontrastu $\mathrm{k}$ těmto individualizačním procesům a $\mathrm{k}$ představě stáŕí jako času pro seberealizaci. Je zřejmé, že se prarodiče i jejich děti snaží vyjednat hranice prarodičovství, přičemž samotní prarodiče vidí péči o vnoučata především jako vědomou, ale nesamozřejmou volbu, závislou na jejich jiných aktivitách a zálibách (Reitzes a Mutran 2004; Hasmanová Marhánková 2013).

Podle těchto zjištění lze očekávat, že čeští prarodiče nebudou ochotní vzdát se svého životního stylu ve prospěch péče o vnoučata. Přesto volný čas seniorů a péče o vnoučata nemusí být nutně v rozporu. Prarodiče mohou se svými vnoučaty vykonávat např́klad nějaký koníček, sportovat apod.

Někteří autoři (Igel a Szydlik 2011; Kuchařová a kol. 2002) také přišli se zjištěním, že prarodiče se do péče o vnoučata zapojují velmi často, a to i velmi intenzivně. Meyer (2014) zaznamenala, že prarodiče jsou dokonce ochotni vzdát se ekonomické aktivity ve prospěch péče o vnoučata. Péči o vnoučata tedy nelze vidět jen jako zátěž, ale i jako důležitou a oblíbenou aktivitu seniorů.

Velmi zajímavé bylo zjištění Hasmanové Marhánkové (2013), že se senioři docházející do seniorských center negativně vymezovali vůči svým vrstevníkům, kteří podle nich nežili aktivně anebo se věnovali v první řadě péči o vnoučata. To je zřejmě důsledkem jednak unifikace seniorů (Degnen 2007; Jones 2006), jednak politiky aktivního stárnutí spojovaného

At’ už se jedná například o tatínky, kteří se svými dětmi tráví více času, přebalují kojence anebo zůstávají s dětmi na rodičovské dovolené, či syny, kteří přebírají péči o stárnoucí rodiče. 
především s individualizací, seberealizací a prodloužením ekonomické aktivity, jež opomíjí zdůraznit i péči o rodinu jako důležitou složku aktivního stárnutí. Péče o vnoučata tak zřejmě není vnímána jako dostatečně aktivní na to, aby byla považována za součást „správného“ aktivního stárnutí.

Podle těchto zjištění ze studie Hasmanové Marhánkové (2013) a za předpokladu, že genderové stereotypy zasahují do vnímání dědečkovství, lze tedy očekávat, že odsouzení dědečků pečujících o vnoučata nebo jiné členy rodiny může být ještě výraznější než v prŕípadě babiček.

Vymezování se vůči neaktivním seniorům může být také náznakem jakýchsi „,nových nerovnostî“ vznikajících právě v důsledku imperativu aktivního stárnutí. Koncept aktivního stárnutí se zdá být v jisté míře diskriminační, nebot' ne každý senior má dobré finanční, zdravotní či jiné podmínky pro to, aby mohl docházet např́ílad do center pro seniory, dále se vzdělávat, déle participovat na trhu práce anebo třeba pečovat o vnoučata (Bury 1995).

Rizikem imperativu aktivního stárnutí je také př́ilišná idealizace důchodu jako období sebenaplnění a volnosti dělat, co chceme a kdy chceme. Období důchodu je chápáno jako období vlastní seberealizace, zájmů, cestování a jiných aktivit, na které nebyl v minulosti čas (Boudiny 2012; Sýkorová 2007). Vzhledem k tomu, že tradičně pečovatelské role přináležely spíše ženám než mužům (Ando 2005; Aronson 1992), je otázkou, zda může být pro muže pečování o děti, tedy o vnoučata, tou aktivitou, na kterou dříve neměli čas, a pro ženy, spíše naopak, možnost věnovat se pro změnu jen sobě, zaměřit se na své cíle, své zájmy.

\section{Rozdíly mezi prarodičovstvím mužư a žen}

Jak již bylo řečeno, zájem o životy, role a zkušenosti starších mužů je poměrně nový (Connell 2005), avšak zdá se, že rozdíly mezi seniory a seniorkami existují. Jak v prožívání prarodičovství, tak v prožívání aktivního stárnutí. Proto bychom při zkoumání seniorů neměli považovat prarodiče za jednu homogenní skupinu a měli zvážit i vliv genderu na jejich role $\mathrm{v}$ rámci rodiny i společnosti.

Rozhodně nelze dědečky vynechat z diskuse o prarodičovství, nebot' mnozí výzkumníci (Tarrant 2012; Roberto et al. 2001) zjistili, že muži se na péči o vnoučata chtějí podílet, a to jakoukoliv formou. Někteří (Tarrant 2012; Millward 1998) dokonce uvádí, že dědečkové se do života vnoučat zapojují stejnou měrou jako babičky. Tato zjištění však podle Manna a Leesona (2010) platí spíše o dědečcích z mladších věkových kohort. Tyto závěry ze zahraničních studií však nelze bez předešlého otestování zobecnit na české dědečky.

Většina sociologů upozorňuje na heterogenitu prarodičovských rolí, jejich proživání i formu (Fairhurst 2003; Tarrant 2012). Shodují se však na tom, že prarodičovská role je důležitou součástí života seniorů - a to i mužů (Harper 2005; Reitzes a Mutran 2004; Ando 2005; Mann 2007; Bates a Taylor 2003; Waldrop a Weber 2001).

Jak vyplývá ze studie Tarrant (2012), dědečkové zastávají spiše formální a vzdálený styl prarodičovstvís. Někteří autoři také hovoří o tom, že dědečkové poskytují svým

$5 \quad$ Tyto termíny pochází z typologie, kterou zkonstruovali Neugarten a Weinstein (1964). Avšak vzhledem $\mathrm{k}$ tomu, že se jedná o zahraniční studii starou padesát let, je třeba se ptát, zda je typologie vůbec platná dnes a zda je o ní možné uvažovat i v českém prostředí. 
vnoučatům především ekonomickou a instrumentální pomoc, jako je například vození k lékaři, vzdělávání, trávení času společně mimo domov ${ }^{6}$, zatímco péče babiček je spojována spíše s domovem a každodenními povinnostmi (Tarrant 2010; Wilton a Davey 2006; Thompson a Whearty 2004; Mann 2007).

Na jedno ze zajímavých specifik dědečkovství ve srovnání s babičkovstvím upozorňují Reitzes a Mutran (2004), již hovoří o tom, že dědečkové mají možnost sami se rozhodnout, zda se do péče o vnoučata chtějí zapojit. A to bez jakéhokoliv nátlaku apriorních očekávání, který mohou pocit’ovat babičky vlivem genderových stereotypů.

Podle zjištění Hasmanové Marhánkové (2013) jsou to právě i genderové stereotypy, které mají vliv na prožívání stárnutí i prarodičovství českých seniorů. Podobný názor mají i Marshall a Katz (2006), kteří v kontrastu se Silver (2003) říkají, že nedochází ke stírání genderových rozdílů, ale spíše nabývají jiných forem7.

Kupříkladu Davidson et al. (2003) se na dědečkovství dívají úplně z jiného úhlu a poukazují na možnost, že dědečkové péčí o vnoučata sobě i dětem vynahrazují čas, který jim nemohli věnovat, když byly malé, například kvůli zaměstnání. Přesto se podle některých studií zdá, že i když dědečkové chtějí o vnoučata pečovat, nemusí jim to být vždy umožněno. Vlivem genderových stereotypů se mohou rodiče obávat svěření vnoučat do péče dědečků, nebot' se domnívají, že by to jako muži nezvládli. Tomu napovídá i skutečnost, že rozvedení dědečci nebo dědečci, kteří žijí bez partnerky, mají nižší šanci na participaci na péči o vnoučata (Millward 1998; Wilton a Davey 2006; Vandell et al. 2003; Di Gessa et al. 2014).

Jedním z dalších rozdílů mezi dědečky a babičkami je i fakt, že v kategorii osob starších 60 let pracuje podle údajů Českého statistického úřadu (ČSÚ 2012) dvojnásobek mužů oproti ženám. Tato skutečnost může vést $\mathrm{k}$ tomu, že dědečkové mají ještě méně volného času než babičky, který by mohli věnovat péči o vnoučata či jiným aktivitám.

I zjištění Hasmanové Marhánkové (2013) o nižší účasti mužů v seniorských centrech podporuje tuto domněnku a zdá se, že zatímco muži se stále upínají k placené práci, ženy chápou aktivní stárnutí jako příležitost dále se vzdělávat, být společenské a věnovat se svým zálibám. ${ }^{8}$ Podle Duxbury, Lyonse a Higginse (2008) má sice péče o vnoučata místo v životech zástupců obou genderů, avšak pouze do té míry, aby měli senioři čas i na jiné své aktivity. To, nakolik ovlivňuje ekonomická aktivita a další aktivity frekvenci hlídání vnoučat českými seniory, je jednou z výzkumných otázek kladených v tomto textu.

6 Jak připomíná i Tarrant (2010), tyto činnosti zcela zapadají do představy maskulinity. Dědečci s dětmi vztah mají, ale spíše mimo domov, který je tradičně arénou žen. Podobně píší i Brandth a Kvande (1998), že i když muži dělají ,„̌̌enskou“ práci, stále ji dělají takovým způsobem, který pasuje do norem hegemonické maskulinity.

7 Tak jako např́klad v př́ípadě studie Hasmanové Marhánkové (2013), která poukazuje na to, že absenci mužů v seniorských centrech spojují jejich klienti i zaměstnanci s představami maskulinity a femininity. Muži byli vnímáni jako ti méně aktivní, neochotní zkoušet nové věci, pasivní a dokonce až líní. Ženy byly popisovány jako aktivní, společenské a odhodlané nezůstat sedět doma a snažit se o sebe starat a být aktivní i v pokročilém věku.

8 Vlivem větší věkové diskriminace starších žen na trhu práce však pro ně může být privátní sféra jediným místem seberealizace. 


\section{Faktory ovlivňující frekvenci hlídání vnoučat dědečky a babičkami}

Prarodičovství jistě není uniformní zkušeností. Způsoby vykonávání této role, frekvence hlídání vnoučat apod. se mohou lišit v závislosti na mnoha faktorech.

Podle Di Gessa et al. (2014) ovlivňují podobu prarodičovské péče o vnoučata charakteristiky prarodičů, rodičů, vnoučat i společenského kontextu. Igel a Szydlik (2011) zase faktory dělí na př́ležitosti, potřeby, rodinnou konfiguraci a kulturně kontextuální strukturu. Igel et al. (2009) pak hovoří o charakteristikách prarodičů, potřebách rodičů, rodinné struktuře a kontextuálních strukturách.

Jak jsem již psala výše, někteří ze zahraničních autorů se domnívají, že míra zapojení dědečků do péče o vnoučata je nižší než v případě babiček. Jiní však toto tvrzení odmítají. Mým cílem je proto v této studii zjistit, zda se liší frekvence hlídání vnoučat dědečky a babičkami a které faktory ji ovlivňují. V následující kapitole proto uvedu faktory ovlivňující frekvenci hlídání vnoučat, jež zahraniční studie zmiňují nejčastěji a o nichž se domnívám, že by mohly mít svůj význam i v českém prostředí.

S genderovými očekáváními ohledně dědečkovství souvisí vliv rodinného stavu dědečka na frekvenci péče o vnoučata. Podle dosavadních zahraničních zjištění (Hank a Buber 2009; Aassve et al. 2012; Igel a Szydlik 2011; Uhlenberg a Hammill 1998) dědečkové, kteří nesdílí domácnost s partnerkou, pečují o vnoučata nejméně. I když jde o dědečka rozvedeného, který nyní žije s novou partnerkou, je jeho péče méně intenzivní a méně častá. To lze vysvětlit kupříkladu tím, že ženy jsou těmi, kdo udržují mezigenerační vztahy, a primárními poskytovateli péče (Ando 2005; Spitze a Logan 1989). Očekávám, že péče o vnoučata v případě českých dědečků bude taktéž limitována přítomností partnerky, která je dle genderových stereotypů zárukou toho, že o dítě bude správně postaráno.

Mnozí zahraniční autoři (Aassve et al. 2012; Igel a Szydlik 2011) se shodují na negativním vlivu ekonomické aktivity a jiných aktivit dědečka, jako jsou např́klad další vzdělávání či vlastní koníčky. Podle závěrů Di Gessa et al. (2014) a Igel a Szydlika (2011) platí, že zaměstnaní prarodiče poskytují péči o vnoučata s menší pravděpodobností než prarodiče v důchodu. Jak jsem psala již výše v tomto textu, péče o vnoučata pro seniory rozhodně není samozřejmá ani automatická. Proto záleží také na dědečcích, nakolik jsou ochotní podřídit své další aktivity a svi̊j život potřebám svých dětí a vnoučat. Na druhou stranu bychom neměli vidět hlídání vnoučat pouze jako břemeno kladené na bedra prarodičů. Volný čas seniorů a hlídání vnoučat se totiž nutně nemusí vzájemně vylučovat. Prarodiče mohou aktivity, na které by jim jinak nemusel zbýt čas, vykonávat společně s vnoučaty. Společný čas tedy mohou trávit naprríklad vykonáváním společných koníčků či sportováním. Přesto však předpokládám, že ekonomická aktivita a další vykonávané aktivity budou snižovat frekvenci hlídání vnoučat.

Dalšími faktory ovlivňujícími prarodičovství jsou podle zahraničních studií věk a zdravotní stav (Verbrugge a Chan 2008; Ando 2005). V naprosté většině př́ipadů jejich výsledky vypovídají o tom, že čím starší prarodiče jsou i čím horší je jejich zdravotní stav, tím méně pečují o svá vnoučata (Aassve et al. 2012; Di Gessa et al. 2014; Verbrugge a Chan 2008). A to především tehdy, když jsou již v důchodu (Hank a Buber 2009; Igel a Szydlik 2011). Po vzoru zahraničních výzkumů tedy očekávám, že horší zdravotní stav a vyšší věk budou omezujícími faktory frekvence péče o vnoučata. 
Jako omezující faktor prarodičovské péče podle zahraničních autorů působí také počet vnoučat, kdy jsou dědečkové a babičky nuceni rozdělit své kapacity mezi větší počet dětí (Aassve et al. 2012; Igel a Szydlik 2011; Dimova a Wolff 2008; Uhlenberg a Hammill 1998). I já předpokládám, že čeští prarodiče jsou ve frekvenci hlídání vnoučat limitováni jejich počtem. Tedy s rostoucím počtem vnoučat se bude snižovat šance prarodičů na jejich časté hlídání.

\section{Data a metoda}

V empirické části budu s použitím dat 4 . vlny projektu SHARE ${ }^{9}$ testovat, jestli výše uvedené faktory ovlivňují, zda a jak moc čeští dědečkové pečují o svá vnoučata.

Data 4. vlny panelového výzkumu SHARE byla sbírána v České republice v roce 2011. Vzorek je reprezentativní pro českou populaci starší 50 let (díky pravděpodobnostnímu výběru a deklarované návratnosti přes $85 \%)^{10}$. Po odstranění chybějících případů z původního počtu 2576 mužů a 3542 žen ${ }^{11}$ jsem po výběru respondentů, kteří mají alespoň jedno vnouče, a po odstranění chybějících př́ípadů u všech proměnných ${ }^{12}$ použitých $\mathrm{v}$ analýze získala 826 dědečků a 1580 babiček.

Jako závisle proměnnou pro logistickou regresi jsem zvolila jednak proměnnou vypovídající o tom, zda dědečkové a babičky hlídají vnoučata $v$ nepřítomnosti jejich rodičů alespoň někdy, či nikoliv, a jednak proměnnou udávající, zda hlídají vnoučata alespoň skoro každý týden, anebo méně často. ${ }^{13}$ Předpokládám, že se v př́padě dědečků a babiček, kteří pečují o vnoučata alespoň skoro každý týden, projeví, nakolik jim péče o vnoučata zasahuje do jejich běžného života. Tedy zda aktivity a placené zaměstnání mají vliv na to, zda dědečkové a babičky pečují o vnoučata intenzivně, či nikoliv.

Jako nezávisle proměnné byly použity následující: věk, rodinný stav, subjektivně hodnocený zdravotní stav, zda prarodič vykonává některou $\mathrm{z}$ aktivit ${ }^{14}$, ekonomická aktivita a počet vnoučat.

9 Survey of Health, Ageing and Retirement in Europe.

10 Více informací o projektu SHARE na www.share-project.org.

$11 \quad \mathrm{Z}$ toho 1484 dědečkủ $(69 \%)$ a 2621 babiček $(80 \%)$.

12 Jedná se o následující proměnné: rok narození, frekvence péče o vnoučata, další vzdělávání, práce jako dobrovolník, jiné aktivity, ekonomická aktivita, počet vnoučat, rodinný stav, subjektivně hodnocený zdravotní stav.

13 Kategorie méně často znamená, že pečují téměř každý měsíc, méně anebo vůbec. Vytvoření této dichotomické proměnné, která se může jevit jako redukcionistická, bylo nevyhnutelné, nebot' při třídění vyššího stupně by $\mathrm{v}$ jednotlivých kategoriích byly nízké počty př́ípadů. Vzhledem $\mathrm{k}$ tomu, že se jedná o úvodní představení tématu dědečkovství a že hlídání vnoučat alespoň skoro každý týden je dostatečně časté na to, aby se mohl projevit vliv ostatních aktivit prarodičů na frekvenci hlídání vnoučat, a také dostatečně vzdálené hlídání vnoučat téměř každý měsíc, jeví se toto řešení jako akceptovatelné. Bohužel v České republice je nedostatek výzkumů vypovídající o populaci prarodičů. Ve většině př́ípadů jde o výzkumy zaměřující se na seniory, mezi nimiž je však množství těch, kteří vnoučata nemají.

14 Jedná se o následující: dobrovolná neplacená či charitativní činnost, účast na vzdělávacím kurzu, účast na sportovních, společenských aktivitách, účast na církevních aktivitách, účast na aktivitách 
Věk byl rozdělen do tří kategorií od 50 do 60 let, od 61 do 74 a od 75 do 100 let, přičemž mne zajímá, zda skutečně více intenzivně pečují v rámci mužů nejmladší dědečci, jak vyplývá ze zjištění zahraničních studií uvedených výše.

Rodinný stav byl použit jako indikátor toho, zda respondent žije v domácnosti s partnerem, či nikoliv (je tedy rozvedený, odloučený, ovdovělý nebo v registrovaném partnerství). Opět se zde držím zjištění uvedených výše a předpokládám, že přítomnost partnerky v domácnosti bude pozitivně ovlivňovat šanci dědečků na péči o vnoučata. ${ }^{15}$ To samé platí i v případě subjektivního zdravotního stavu, kdy očekávám, že pokud respondent hodnotil své zdraví alespoň jako dobré, pak budou jeho šance na péči o vnoučata vyšší.

V prŕípadě dalších aktivit v souladu s předpoklady zahraničních kolegů očekávám, že budou spíše přispívat k nižším šancím na péči o vnoučata. V analýze použiji dichotomickou proměnnou, která indikuje, zda respondent vykonává alespoň jednu z daných aktivit. I ekonomická aktivita respondentů bude zřejmě ovlivňovat pečování o vnoučata spíše negativně.

Poslední nezávislou proměnnou je pak počet vnoučat, rozdělený do tří kategorií: jedno, dvě až pět vnoučat a šest a více vnoučat. Očekávám, že více vnoučat bude spíše negativně ovlivňovat denní péči o vnoučata, nebot' dědeček bude muset rozdělit svůj čas i energii mezi více dětí. Na druhou stranu se může jednat o osoby, které se silně orientují a zaměřují na rodinu, samy mají hodně dětí a pak mají také hodně vnoučat, o něž se starají.

Vliv jednotlivých proměnných budu testovat pomocí modelů logistické regrese, které budu srovnávat za použití Waldova testu a Bayesovského informačního kritéria (BIC). Samotné analýze bude ještě předcházet krátká deskripce českých dědečků a babiček na základě procentuálních distribucí získaných z dat projektu SHARE.

\section{Analýza}

Podle dat z projektu SHARE je podíl dědečků mezi českými muži $72 \%$, podíl babiček mezi ženami pak $81 \%$. Po odstranění chybějících případů u všech proměnných použitých v analýze je to pak $69 \%$ a $80 \%$.

Jak vidíme v grafu 1, procentuální distribuce frekvence hlídání vnoučat se u dědečků a babiček nijak výrazně neliší. Pouze $\mathrm{v}$ případě péče o vnoučata téměř každodenně je podíl babiček o $3 \%$ vyšší než podíl dědečků $(8 \%)$ a také dědečků, kteří o svá vnoučata nepečují vůbec, je o $4 \%$ více (56\%) než babiček, které se o svá vnoučata nestarají. Pokud prarodiče o svá vnoučata pečují, pak se jedná nejčastěji o hlídání téměř každý týden $(16 \%$ dědečků i babiček). Zdá se tedy, že v České republice neplatí, že dědečkové o svá vnoučata nepečují nebo pečují výrazně méně než babičky. I ve frekvenci péče jsou jen minimální rozdíly.

politické organizace nebo občanské iniciativy, četba knih, časopisů nebo novin, luštění kř́žževek, číselných hádanek, hraní slovních her nebo sudoku, hraní karet nebo her jako šachy.

$15 \mathrm{Z}$ důvodu předpokladu jistého působení genderových stereotypů, jak byly popsány výše, jsou proto registrovaní partneři zahrnuti mezi ty, kteří s partnerkou nežijí. 
Graf 1: Procentuální podíly dědečků a babiček nad 50 let podle frekvence péče

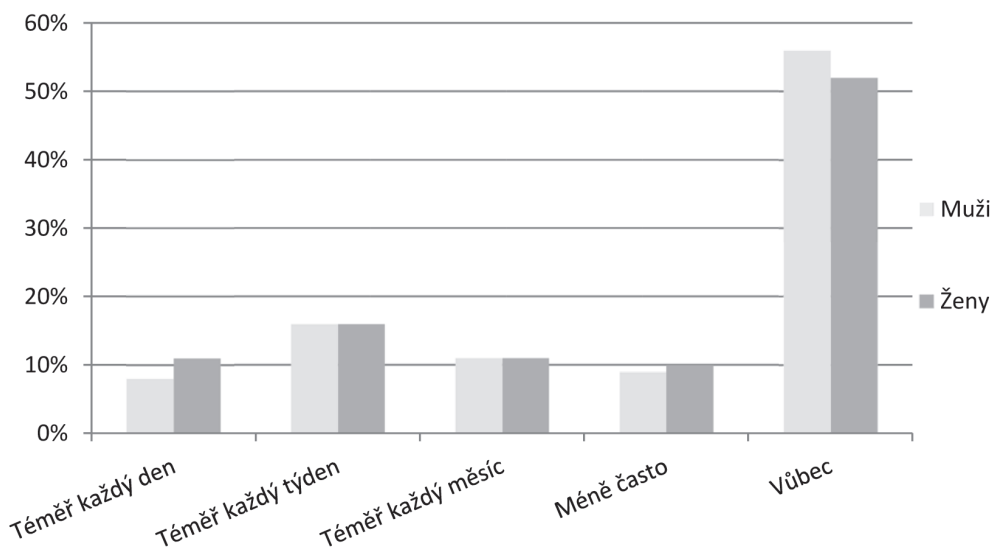

Zdroj: SHARE 4.vlna, 2011. N=2406

Podle grafu 2 se o svá vnoučata stará alespoň téměř každý týden $24 \%$ dědečků a $27 \%$ babiček.

Graf 2: Procentuální podíly dědečků a babiček nad 50 let pečujících alespoň téměř každý týden

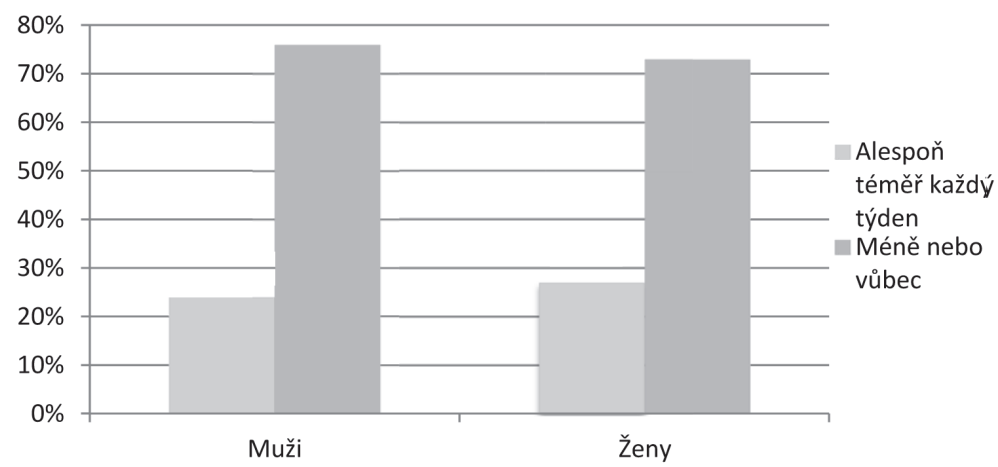

Zdroj: SHARE 4.vlna, 2011. N=2406

Podíváme-li se na detailnější rozložení frekvence péče o vnoučata dědečků a babiček různých věkových kategorií v grafu 3, vidíme, že téměř denně pečuje o vnoučata nejvíce dědečků ve věkové kategorii 60-70 let (11\%). To může být způsobeno tím, že v daném věku už jsou zřejmě v důchodu, a mají tedy více času na péči o vnoučata. V případě žen to však neplatí (největší podíl babiček pečujících o vnoučata téměř každý den je ve věkové kategorii 50 až 59 let), což může znamenat, že ženy o vnoučata pečují v každém životním období, bez ohledu na to, zda mají práci, nebo už jsou v důchodu. Lze v tom vidět i náznak potvrzení 
genderového stereotypu, který ženám přisuzuje péči o druhé a mužům placenou práci. Ve věkové kategorii 50-59 let totiž o vnoučata téměř každý den pečuje $15 \%$ babiček, avšak dědečků pouze $7 \%$. Velký nárůst počtu prarodičůn, kteří nepečují vůbec, ve věkové kategorii 70-100 let lze zřejmě vysvětlit nejen zhoršujícím se zdravotním stavem prarodičů, ale také skutečností, že v tomto věku jsou už vnoučata většinou dospělá, a nepotřebují tak každodenní hlídání.

Graf 3: Procentuální podíly dědečkủ a babiček jednotlivých věkových kategorií podle frekvence péče

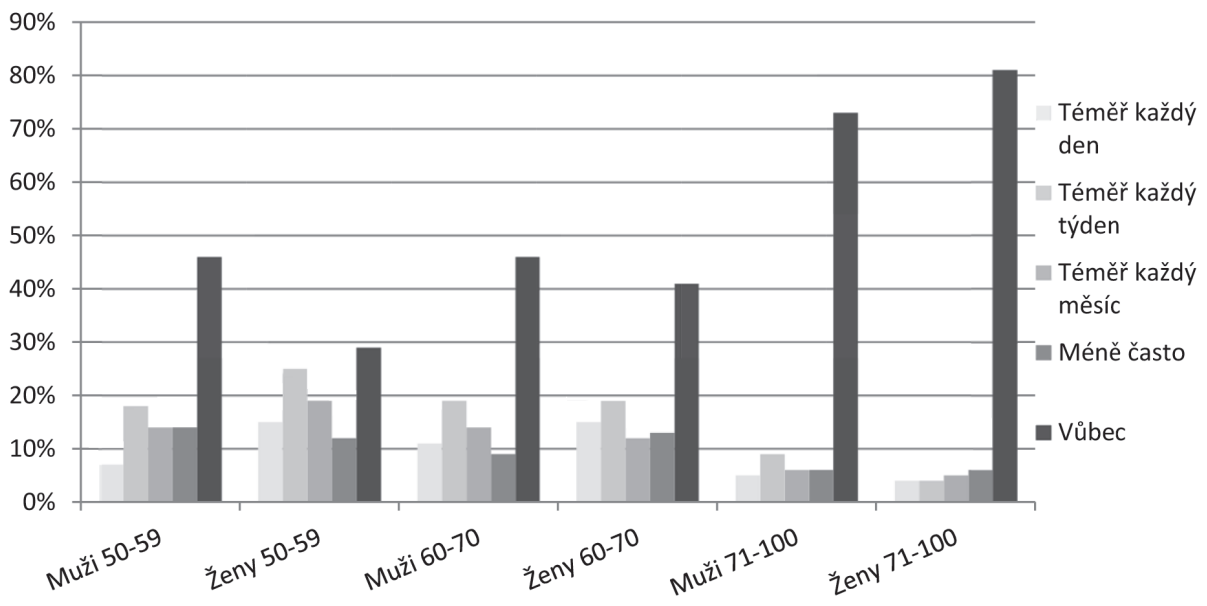

Zdroj: SHARE 4.vlna, 2011. N=2406

V analytické části se nejdříve budu zabývat tím, jaké faktory mají vliv na to, zda prarodiče o vnoučata pečují alespoň někdy, či vůbec, a zda pečují alespoň téměř každý týden, či méně často, pomocí postupného budování modelu logistické regrese. Srovnáním těchto dvou modelů mám pak možnost posoudit, zda se míra vlivu faktorů či faktory ovlivňující frekvenci péče nějak liší.

Testován byl vliv pohlaví, zdravotního stavu, rodinného stavu i interakce zdraví a rodinného stavu, kdy jsem předpokládala, že dědečkové, kteří žijí sami a cítí se zdravotně hưr̆, o vnoučata spíše pečovat nebudou, avšak vliv této interakce nebyl signifikantní. Dále jsem se zajímala o to, zda o péči o vnoučata rozhoduje věk prarodiče, jeho ekonomická aktivita, další aktivity, které vykonává, a počet vnoučat. Testovala jsem také interakci pohlaví a rodinného stavu, kdy v souladu s výše uvedenými zahraničními studiemi předpokládám, že dědečci, kteří žijí bez partnerky, budou mít menší šanci na to, že budou pečovat o svá vnoučata, než babičky bez partnera.

Srovnání jednotlivých modelů šancí prarodičů na hlídání vnoučat alespoň někdy uvádím v tabulce 1. Jako nejvhodnější se podle Waldova testu i hodnoty BIC jeví model devátý. Podle tohoto modelu mohu říci, že to, zda čeští dědečkové o vnoučata pečují, ovlivňuje rodinný stav dědečka, subjektivní zdravotní stav, věk, počet vnoučat a také se potvrdil vliv interakce pohlaví a rodinného stavu. To znamená, že míra vlivu rodinného stavu na péči 
o vnoučata je u babiček a dědečků rozdílná. Vliv ekonomické aktivity, jiných aktivit a interakce zdraví a rodinného stavu byl nesignifikantní na hladině významnosti 0,05 .

Tabulka 1: Srovnání modelů logistické regrese závislosti péče vs. absence péče prarodičů o vnoučata na různých faktorech

\begin{tabular}{|l|l|c|c|c|c|c|}
\hline & & Waldův test & Sig. & d.f. & BIC & N \\
\hline M1 & Pohlaví & & 0,066 & 2 & 3342,19 & 2406 \\
\hline M2:M1 & M1 + Zdraví & 47,82 & $0,000^{*}$ & 3 & 3302,16 & 2406 \\
\hline M3:M2 & M2+Rodinný stav & 81,88 & $0,000^{*}$ & 4 & 3228,07 & 2406 \\
\hline M4:M3 & M1+Zdravi*Rod. stav & 0,87 & 0,351 & 5 & 3234,98 & 2406 \\
\hline M5:M3 & M3+Věk & 245,14 & $0,000^{*}$ & 6 & 2998,50 & 2406 \\
\hline M6:M5 & M5+Pohlavi*Rod.stav & 9,88 & $0,017^{*}$ & 7 & 2996,40 & 2406 \\
\hline M7:M6 & M6+Ekonomická aktivita & 0,00 & 0,954 & 8 & 3004,18 & 2406 \\
\hline M8:M6 & M6+Aktivity & 0,58 & 0,446 & 8 & 3003,60 & 2406 \\
\hline M9:M6 & M6+Počet vnoučat & $\mathbf{1 3 , 7 5}$ & $\mathbf{0 , 0 0 1 *}$ & $\mathbf{9}$ & $\mathbf{2 9 9 8 , 2 2}$ & $\mathbf{2 4 0 6}$ \\
\hline
\end{tabular}

Zdroj: SHARE 4. vlna, 2011. N=2406

*Signifikantní na hladině významnosti 0,05

Výsledný model je zobrazený v tabulce 2. O rozdílnosti prarodičovské péče dědečků a babiček vypovídá zjištění, že dědečkové žijící bez partnerky mají při kontrole všech nezávisle proměnných o 51 \% menší šanci na péči o vnoučata než babičky bez partnera. Podle tabulky 2 zvyšuje soužití s partnerem či partnerkou šance prarodičů na péči o 39\%. Šance dědečků žijících s partnerkami na hlídání vnoučat je pak o 7\% menší než šance babiček. Zdá se tedy, že by v České republice přece jen mohly přetrvávat genderové stereotypy, kdy muži jsou vnímáni jako ti, jimž péče o děti nepř́isluší nebo ji bez partnerky v domácnosti nezvládnou. Př́itomnost partnerky dědečka tak může být jakousi zárukou toho, že o vnoučata bude dobře postaráno.

Je také možné, že si dědečkové nevytvořili dostatečně silné vztahy s vnoučaty a ty pak snadno ochladly bez přítomnosti babičky či partnerky, tedy žen, jako těch co udržují mezigenerační vztahy (Ando 2005). Další z př́ičin pak může být i negativní vliv rozvodu prarodičů či rodičů na frekvenci kontaktu s vnoučaty (viz Millward 1998; Wilton a Davey 2006; Vandell et al. 2003; Di Gessa et al. 2014), anebo také slabší soudržnost rodiny.

V prŕípadě věkových kategorií pak platí, že čím starší je prarodič, tím menší má šanci na péči o vnoučata. Ve třetí věkové skupině od 75 do 100 let je šance na péči dokonce 0,15 krát menší než v případě dědečků a babiček od 50 do 74 let. Potvrdila se tak zjištění zahraničních studií, že s rostoucím věkem šance na péči o vnoučata klesá. Nepotvrdilo se ale, že dědečci a babičky, kteří ještě jsou ekonomicky aktivní, pečují o vnoučata méně než ti, kteří už jsou v důchodu (vliv ekonomické aktivity nebyl signifikantní na hladině 0,05). Nesignifikantní byl i vliv jiných aktivit. Nemohu tedy posoudit, zda si čeští dědečci a babičky na pečování o vnoučata nachází čas, i když pracují anebo vykonávají jiné aktivity. 
Podle modelu v tabulce 2 také platí, že čím více má prarodič vnoučat, tím větší šance má na hlídání alespoň jednoho z nich.

Tabulka 2: Výsledný model logistické regrese závislosti péče vs. absence péče prarodičů o vnoučata na různých faktorech.

\begin{tabular}{|l|c|c|c|}
\hline & Poměr šancí & Standardní chyba & Sig. \\
\hline Muži & $\mathbf{0 , 4 9}$ & 0,083 & $0,000^{*}$ \\
\hline Soužití s partnerem & $\mathbf{1 , 3 9}$ & 0,157 & $0,002^{*}$ \\
\hline Horší zdravotní stav & 0,72 & 0,065 & $0,001^{*}$ \\
\hline Pohlavi*'Rod. stav & $\mathbf{1 , 9 2}$ & 0,402 & $0,002^{*}$ \\
\hline 61-74 let & 0,65 & 0,073 & $0,001^{*}$ \\
\hline 75-100 let & $\mathbf{0 , 1 5}$ & 0,020 & $0,000^{*}$ \\
\hline 2 až 5 vnoučat & 1,50 & 0,188 & $0,001^{*}$ \\
\hline 6 a více vnoučat & 1,75 & 0,281 & $0,001^{*}$ \\
\hline
\end{tabular}

Zdroj: SHARE 4.vlna, 2011. $\mathrm{N}=2406$

*Signifikantní na hladině významnosti 0,05

Pro vysvětlení hlídání vnoučat alespoň téměř každý týden je podle Waldova testu nejvhodnější model, v němž jsou zahrnuty proměnné pohlaví, zdraví, rodinný stav, věk, počet vnoučat a interakce pohlaví a rodinného stavu. Ani v tomto př́padě se tedy nepotvrdil vliv ekonomické ani jiných aktivit (byl nesignifikantní na hladině významnosti 0,05 ).

Podle zvoleného modelu šancí prarodičů na časté hlídání vnoučat ${ }^{16} \mathrm{v}$ tabulce 3 není signifikantní vliv pouze věkové kategorie od 61 do 74 let. Při časté péči se ale potvrdil silný vliv pohlaví na péči o vnoučata, kdy dědečci mají o $53 \%$ nižší šanci na častější hlídání vnoučat než babičky. Žije-li prarodič s partnerem, pak má o $30 \%$ vyšší šanci na intenzivní péči o vnoučata. I v tomto modelu se potvrdil vliv interakce pohlaví a rodinného stavu. Dědečci žijící s partnerkami mají o $5 \%$ nižší šance na častější hlídání vnoučat než babičky s partnery.

Horší zdravotní stav snižuje šance dědečků a babiček na časté hlídání vnoučat o $37 \%$. I stoupající věk má opět negativní vliv na šanci, že se bude dědeček o vnoučata starat alespoň téměř každý týden. Ti nejstarší prarodiče (od 75 do 100 let) mají oproti těm mladším o 77\% menši šanci na častou péči o vnoučata.

Platí také, že čím více má dědeček vnoučat, tím větší má šanci na to, že bude alespoň o jedno z nich pečovat alespoň téměr každý týden (o $47 \%$ vyšší v př́ipadě 2 až 5 vnoučat a o $53 \%$ v př́padě 6 a více vnoučat). To je zcela $v$ rozporu s tím, co uváděli zahraniční autoři, kteří tvrdili, že více vnoučat znamená méně frekventovanou péči, protože prarodič musí svůj čas rozdělit mezi více potomků. Důvodem může být již zmiňovaný důraz kladený na rodinu.

16 Termín časté, častější, intenzivní anebo frekventované hlídání vnoučat budu v následujícím textu používat pro téměř každotýdenní či téměř každodenní hlídání. 
Tabulka 3: Výsledný model logistické regrese závislosti časté péče prarodičů o vnoučata na různých faktorech

\begin{tabular}{|l|c|c|c|}
\hline & Poměr šancí & Standardní chyba & Sig. \\
\hline Muži & 0,47 & 0,102 & $0,000^{*}$ \\
\hline Soužití s partnerem & $\mathbf{1 , 3 0}$ & 0,159 & $0,030^{*}$ \\
\hline Horší zdravotní stav & 0,63 & 0,064 & $0,000^{*}$ \\
\hline Pohlavi*Rod. stav & $\mathbf{2 , 0 6}$ & 0,516 & $0,004^{*}$ \\
\hline 61-74 let & 0,85 & 0,098 & 0,163 \\
\hline 75-100 let & 0,23 & 0,035 & $0,000^{*}$ \\
\hline 2 až 5 vnoučat & 1,47 & 0,205 & $0,005^{*}$ \\
\hline 6 a více vnoučat & 1,53 & 0,274 & $0,018^{*}$ \\
\hline
\end{tabular}

Zdroj: SHARE 4.vlna, 2011. $\mathrm{N}=2406$

*Signifikantní na hladině významnosti 0,05

Nyní se budu podrobněji věnovat srovnání efektů nezávisle proměnných na dědečkovství a babičkovství v případech, kdy hlídají vnoučata často a kdy je nehlídají vůbec.

V tabulce 4 jsou zaznamenány výsledné modely vysvětlující nepečování o vnoučata $\mathrm{v}$ př́padě babiček a dědečků. Šance dědečků na to, že nebudou svá vnoučata hlídat vůbec, ovlivňuje rodinný stav a věk. Šance babiček pak navíc zdravotní stav a počet vnoučat.

Z tabulky 4 vyplývá, že je-li dědeček starší 75 let, pak má o $225 \%$ větší šanci na to, že nebude participovat na péči o vnoučata. Pokud žije s partnerkou, jsou jeho šance na nehlídání vnoučat o $60 \%$ nižší. $V$ prrípadě babiček má největší vliv nejstarší věková kategorie, kdy babičky nad 75 let mají o $802 \%$ vyšší šance na to, že nebudou o vnoučata pečovat vůbec. Velký rozdíl mezi dědečky a babičkami je opět ve vlivu rodinného stavu. V př́padě babiček je takřka poloviční, nebot' pokud žijí s partnerem, šance, že nebudou vnoučata hlídat vůbec, je o $23 \%$ menší než šance babiček žijících bez partnera. Šance babiček na to, že nebudou pečovat o vnoučata, se snižují také s počtem vnoučat.

Tabulka 4: Srovnání výsledných modelů logistické regrese závislosti absence péče dědečků a babiček o vnoučata na různých faktorech

\begin{tabular}{|l|c|c|c|c|c|c|}
\hline & \multicolumn{2}{|c|}{ Poměr šancí } & \multicolumn{2}{c|}{ Standardní chyba } & \multicolumn{2}{c|}{ Sig. } \\
\hline & Dědečci & Babičky & Dědečci & Babičky & Dědečci & Babičky \\
\hline Horší zdravotní stav & - & 1,52 & - & 0,172 & - & $0,000^{*}$ \\
\hline Soužíí s partnerem & $\mathbf{0 , 4 0}$ & $\mathbf{0 , 7 7}$ & 0,067 & 0,089 & $0,000^{*}$ & $0,021^{*}$ \\
\hline 61-74 let & 1,03 & 1,80 & 0,197 & 0,256 & $\mathbf{0 , 8 5 9}$ & $0,000^{*}$ \\
\hline 75-100 let & $\mathbf{3 , 2 5}$ & $\mathbf{9 , 0 2}$ & 0,675 & 1,512 & $0,000^{*}$ & $0,000^{*}$ \\
\hline 2 až 5 vnoučat & - & 0,71 & - & 0,114 & - & $0,030^{*}$ \\
\hline 6 a více vnoučat & - & 0,53 & - & 0,108 & - & $0,002^{*}$ \\
\hline
\end{tabular}

Zdroj: SHARE 4.vlna, 2011. N=2406

* Signifikantní na hladině významnosti 0,05 
V prŕípadě časté péče (viz tabulka 5) jsou v modelu zahrnuty jiné proměnné než v př́ipadě nepečování. Šance dědečků na časté hlídání vnoučat snižuje horší zdravotní stav a věk, šance babiček pak navíc ještě ekonomická aktivita. Soužití s partnerem v př́padě dědečků opět výrazně zvyšuje šance na časté hlídání vnoučat $(2,68 \mathrm{krát})$. V případě babiček byl však tento vliv nesignifikantní. Horší zdravotní stav snižuje šance na časté hlídání vnoučat dědečky i babičkami přibližně stejnou měrou $(0,55 \mathrm{krá}$ a $0,67 \mathrm{krá})$. V př́padě babiček se projevil také vliv ekonomické aktivity na šance na časté hlídání vnoučat. Potvrdilo se v souladu se zjištěními ze zahraničních studií, že ekonomická aktivita snižuje šance prarodičů na péči o vnoučata. Šance pracujících babiček na časté hlídání vnoučat je tedy o $35 \%$ nižší než babiček ekonomicky neaktivních. V př́ípadě dědečků byl vliv ekonomické aktivity bohužel nesignifikantní, takže nelze srovnat vliv ekonomické aktivity na šance dědečků a šance babiček na častou péči o vnoučata.

Zajímavé je zjištění, že nejstarší dědečkové mají větší šance na časté hlídání vnoučat než nejstarší babičky. Šance babiček starších 75 let na častou péči o vnoučata je o 87\% menší než u mladších babiček. V př́ípadě nejstarších dědečků jsou pak šance na časté hlídání jen o 46\% menší než šance mladších dědečků. Abych zjistila, zda přítomnost partnera v domácnosti ovlivňuje šance na časté hlídání vnoučat výrazněji v nejstarší věkové kategorii, testovala jsem také interakci rodinného stavu a věku. Její vliv byl však nesignifikantní na hladině významnosti 0,05 .

Tabulka 5: Srovnání výsledných modelů logistické regrese závislosti časté péče dědečků a babiček o vnoučata na různých faktorech

\begin{tabular}{|l|c|c|c|c|c|c|}
\hline & \multicolumn{2}{|c|}{ Poměr šancí } & \multicolumn{2}{c|}{ Standardní chyba } & \multicolumn{2}{c|}{ Sig. } \\
\hline & Dědečci & Babičky & Dědečci & Babičky & Dědečci & Babičky \\
\hline Horší zdravotní stav & 0,55 & 0,67 & 0,097 & 0,084 & $0,001^{*}$ & $0,001^{*}$ \\
\hline Soužití s partnerem & $\mathbf{2 , 6 8}$ & $\mathbf{1 , 2 4}$ & 0,58 & 0,154 & $0,000^{*}$ & $\mathbf{0 , 0 8 0}$ \\
\hline 61-74 let & 1,15 & 0,65 & 0,246 & 0,109 & 0,507 & $0,011^{*}$ \\
\hline 75-100 let & $\mathbf{0 , 5 4}$ & $\mathbf{0 , 1 3}$ & 0,133 & 0,028 & $0,013^{*}$ & $0,000^{*}$ \\
\hline Ekonomická aktivita & - & $\mathbf{0 , 6 5}$ & - & 0,129 & - & $0,029^{*}$ \\
\hline
\end{tabular}

Zdroj: SHARE 4.vlna, 2011. N=2406

*Signifikantní na hladině 0,05

\section{Závěr a diskuze}

Cílem této studie bylo poskytnout počáteční vhled do neprozkoumaného tématu dědečkovství, představit faktory, které mohou dědečkovství ovlivňovat, některé z nich rovnou pomocí logistické regrese otestovat, srovnat dědečky a babičky a především také inspirovat k tématům výzkumů spojených s dědečky, jejich rolemi v rámci rodiny a s prarodičovskou péčí vůbec.

Upozornila jsem na málo prozkoumané téma dědečkovství v české sociologii, proměny českého dědečkovství, jeho možný význam v kontextu aktivního stárnutí a shromáždila jsem některá teoretická východiska pro jeho další výzkum včetně problematiky genderových 
stereotypů $\mathrm{v}$ prarodičovské péči. Uvádím tak čtenáře do problematiky dědečkovství v kontextu mnoha souvislostí, jako jsou demografické a sociální změny, genderové stereotypy a aktivní stárnutí.

V této studii jsem se zaměřovala na hlídání vnoučat prarodiči a na jiné formy pomoci, které mohou dědečci a babičky vnoučatům a jejich rodičům poskytovat, jako jsou např́klad finanční a instrumentální pomoc, které někteří zahraniční autoři považují za typicky mužské (Wilton a Davey 2006; Thompson a Whearty 2004; Mann 2007). Zajímavé by mohlo být srovnání, jaké charakteristiky spojují dědečky, kteří o vnoučata pečují, kteří pomáhají spíše finančně a kteří spíše instrumentálně.

Podle výsledků (viz graf 1) se zdá, že představa dědečků jako těch, co nepečují o vnoučata a ani nechtějí, je už přežitek. Přesto výsledky analýzy ukázaly, že pohlaví má velký vliv na to, zda prarodiče o vnoučata pečují, či ne, a zda pečují alespoň téměř každý týden, anebo méně často (viz tabulka 2 a 3 ). Jedním ze zajímavých zjištění této studie je tedy to, že ačkoliv podíl pečujících dědečků je mezi českými dědečky velký a procentuální distribuce dědečků napříč různými frekvencemi hlídání vnoučat se nijak výrazně neliší od distribuce babiček, jsou jejich šance na hlídání vnoučat výrazně snižovány tím, že jsou muži. Tento negativní vliv je ještě výrazně silnější pro muže, kteří žijí bez partnerky. $Z$ toho lze usuzovat, že ženy a babičky v České republice skutečně fungují jako záruka toho, že o vnoučata bude dobře postaráno. Zjistila jsem tedy, že $\mathrm{v}$ české společnosti zrejmě ještě stále působí genderové stereotypy o pečujících ženách a spíše pracujících mužích (Gilleard a Higgs 2000; Silver 2003; Wilton a Davey 2006; Gradman 1994).

Z tabulek 4 a 5 je zřejmé, že vliv jednotlivých faktorů na frekvenci hlídání vnoučat dědečky a babičkami se liší. Přesto procentuální rozložení babiček a dědečkủ napříč jednotlivými kategoriemi frekvence hlídání vnoučat je v České republice takřka identické. Z toho tedy vyplývá, že dědečkové pečují o vnoučata stejně často jako babičky, ale to, zda hlídají vnoučata často, či vůbec, je ovlivňováno nejen některými odlišnými faktory, ale i faktory stejnými, avšak různou měrou. Faktory podmiňující frekvenci hlídání vnoučat babičkami a míra jejich vlivu se také liší od těch, které podmiňují hlídání vnoučat dědečky. Výsledná frekvence hlídání vnoučat je tedy pro obě pohlaví stejná, avšak vede k ní rozdílná cesta, což ukazuje ve prospěch domněnky některých zahraničních autorů, že babičky a dědečkové prožívají prarodičovství jinak (Tarrant 2012; Bates 2009; Millward 1997; Connell 2005).

Když srovnáme údaje v tabulkách 1 a 3 , vidíme, že míra vlivu jednotlivých faktorů na poskytování alespoň nějaké péče a časté péče o vnoučata se nijak významně neliší. $Z$ toho tedy mohu usuzovat, že mezi různými frekvencemi hlídání vnoučat není př́liš velký rozdíl, co se týče vlivu jednotlivých faktorů. Samozřejmě s výjimkou takřka každodenní péče, která má jistě mnohá specifika, jež by si zasloužila samostatnou studii. V př́ípadě každodenní péče si totiž musí prarodiče vyčlenit nesrovnatelně více času na péči o vnoučata, a to zejména jedná-li se o vnoučata s nízkým věkem. Kupříkladu Igel a Szydlik (2011) a Di Gessa et al. (2014) zjistili, že věk vnoučat rozhoduje o tom, zda prarodiče o svá vnoučata pečují a jak často. Nejvyšší pravděpodobnost péče prarodiči byla $\mathrm{v}$ př́padě vnoučat přibližně od 4 do 6 let, nejmenší pak v prrípadě vnoučat od 12 do 15 let. Igel a Szydlik (2011) také uvádí, že nejintenzivnější péče je poskytována dětem do tří let, což lze považovat za projev toho, že rodiče nechají malá vnoučata s prarodiči méně často, ale když už ano, je péče o to 
intenzivnější. Tuto hypotézu však na datech projektu SHARE nebylo možné otestovat, nebot' v dotazníku chybí otázka na věk vnoučat.

Jedním ze zajímavých zjištění této studie je, že dědečkové mají větší šanci na to, že budou o některé z vnoučat pečovat denně, pokud mají více než jedno vnouče, což je v rozporu se zjištěními ze zahraničních studií (Igel a Szydlik 2011; Di Gessa et al. 2014). Z toho mohu usuzovat, že bud' dědečkové svou péči mezi vnoučata rozdělují velmi nerovnoměrně, anebo se může jednat například o vnoučata od jednoho rodiče, případně hlídají více vnoučat současně. Distribuce péče i finančních darů dědečků a babiček mezi vnoučata je dalším tématem, které čeká na zpracování.

$\mathrm{V}$ této stati jsem potvrdila vliv věku a rodinného stavu dědečků na šance, že budou pečovat o svá vnoučata alespoň někdy (v př́ípadě babiček se projevil i vliv počtu vnoučat) a že časté hlídání vnoučat ovlivňuje vliv rodinného stavu, věku, počtu vnoučat a zdravotního stavu (u babiček má vliv i ekonomická aktivita). Největší šanci na častou péči o vnoučata mají podle mých závěrů dědečci, kteří žijí s partnerkou, cítí se dobře po zdravotní stránce a nejsou starší než 61 let. Vliv aktivit a ekonomické aktivity se ukázal jako bezvýznamný. Šance na to, že dědečci nebudou hlídat vnoučata vůbec, se zvyšují s horším zdravotním stavem, snižují soužitím s partnerkou a rapidně zvyšují s věkem. Nepotvrdil se vliv ekonomické aktivity ani dalších aktivit. V případě babiček je vliv věku na šanci, že nebudou svá vnoučata hlídat vůbec, takřka čtyřikrát větší než v prrípadě dědečků. To může být způsobeno např́klad i tím, že v pokročilém stáŕí už ženy jednoduše nechtějí pečovat o jiné.

Tato „úvodní“ studie je limitovaná především dostupností dat vhodných pro analýzu dědečků. $\mathrm{V}$ důsledku nízkého počtu případů při třídění vyššího stupně totiž dochází $\mathrm{k}$ tomu, že nelze prostřednictvím regresních modelů zkoumat všechny vztahy a faktory, které by zkoumány být měly. K regresním modelům uváděným v této studii by zajisté bylo vhodné přidat např́klad ještě geografickou vzdálenost vnoučat (Tarrant 2010; Aassve et al. 2012), kvalitu vztahů dědečků s rodiči jejich vnoučat, rodinný stav jejich rodičů (Vandell et al. 2003; Di Gessa et al. 2014), motivy prarodičů jako dárců péče o vnoučata a mnoho dalších faktorů, které zřejmě mají na dědečkovství vliv.

Jak jsem již ukázala v této stati, dědečkovství je důležitou součástí aktivního stárnutí a rolí, která je pro muže ve stáŕí důležitá stejně jako pro ženy (Uhlenberg 2005; Hagestad 1987; Cherlin a Furstenberg 1986). Proto by se měli o téma dědečkovství zajímat nejen výzkumníci, ale i veřejná politika a prosazovatelé konceptu aktivního stárnutí, kteří v definicích toho „správného“ stáŕí často zapomínají právě na prarodičovskou péči. Vzhledem k tomu, že aktivní stárnutí má umožnit stárnoucím jedincům seberealizaci a má jim přinášet tedy uspokojení, bylo by zřejmě velmi zajímavé sledovat, která z dimenzí aktivního stárnutí přispívá ke spokojenosti nejen dědečků, ale i babiček.

Dědečkovství je třeba také chápat pouze jako jednu z rolí stárnoucích mužů. Musíme uvážit, že mají také jiné zájmy a jiné cíle, než je péče o vnoučata. Kvalitativní výzkum by se měl zaměřit právě na odhalení motivů dědečků, co se týče péče o vnoučata, a také na to, zda dědečci sami pocit’ují vliv genderových stereotypů a jak je dědečkovská role vyjednávána v kontextu jiných aktivit dědečků. Podle zde prezentovaných regresních modelů se však zdá, že jiné zájmy, koníčky a aktivity nemají signifikantní vliv na to, zda dědečkové pečují 
o vnoučata a jak často. Negativní vliv ekonomické aktivity se projevil pouze v př́ípadě babiček pečujících o vnoučata alespoň téměř každý týden (viz tabulka 5).

Pokud chápeme aktivní stárnutí jako př́ležitost dělat to, na co v minulosti nebyl čas (Boudiny 2012; Sýkorová 2007), pak můžeme předpokládat, že muži, jakožto především pracující a ti, kteří nemohli naplno pečovat o své vlastní děti, budou chtít péčí o vnoučata vynahradit tento nedostatek nejen sobě, ale i svým dětem.

Ve studii Hasmanové Marhánkové (2013) jsem však narazila na to, že aktivní senioři mají tendenci ostře se vymezovat vůči prarodičům, kteří pečují o vnoučata až příliš a nemyslí na nic jiného. Je proto důležité dívat se na koncept aktivního stárnutí v širším kontextu života seniorů a uvažovat i o tom, že imperativ aktivity ve stáŕí může působit i diskriminačně, nebot' ne všichni senioři mohou kvůli zdravotní či finanční situaci stárnout aktivně. Aktivní stárnutí by se tedy snadno mohlo stát zdrojem nových nerovností ve společnosti, přičemž právě dědečkovství by vlivem genderových stereotypů mohlo být odsuzováno ještě výrazněji. Zde je důležité znovu připomenout, že ne všechny definice aktivního stárnutí dostatečně zdůrazňují péči o prríbuzné jako formu aktivního stárnutí a tím zřejmě přispívají k chápání prarodičovství jako něčeho podřadného.

Oblastí, které jsem se zde nevěnovala, ale určitě by neměla být opomenuta, je výzkum toho, jak dědečkové vnímají péči o vnoučata, zda přispívá k jejich blahu či spokojenosti, a také jak péči dědečků vnímají sama vnoučata.

Velmi obsáhlým tématem spojeným s dědečkovstvím jsou také motivy prarodičovské péče. Zahraniční sociologové v této souvislosti hovoří o výměnném (recipročním) a altruistickém modelu mezigenerační výměny (Dimova a Wolff 2008; McGarry a Schoeni 1997; Cox 1987). Testování platnosti těchto dvou modelů by mělo být předmětem dalších výzkumů, stejně jako to, jak dědečkové a babičky zařazují péči o vnoučata mezi jiné své aktivity, jak velký prostor jí ve svých životech dávají a jaký význam má prarodičovství pro ně samotné i pro vnoučata.

\section{Literatura}

AASSVE, Arnstein, Elena MERONI a Chiara PRONZATO. Grandparenting and Childbearing in the Extended Family. European Journal of Population, 2012, roč. 28, č. 4, s. 499-518.

ALBRECHT, Ruth. The parental responsibilities of grandparents. Marriage and Family Living, 1954, roč. 16, č. 3, s. 201-204. ISSN 348486.

ANDO, Kiwamu. Grandparenting: Crossroads between gender and ageing. International Journal of Japanese Sociology, 2005, roč. 14, č. 1, s. 32-51. ISSN 09187545.

ANDREWS, Molly. The seductiveness of agelessness. Ageing and Society, 1999, roč. 19, č. 3, s. 301-318. ISSN 0144686X.

ARONSON, Jane. Old women's experiences of needing care: Choice or compulsion? Canadian Journal on Aging, 1990, roč. 6, č. 1, s. 234-247. ISSN 07149808.

ARONSON, Jane. Women's sense of responsibility for the care of old people: "But who else is going to do it?" Gender \& Society, 1992, roč. 6, č. 1, s. 8-29. ISSN 08912432.

BATES, James S. Generative grandfathering: A conceptual framework for nurturing grandchildren. $M a-$ rriage and Family Review, 2009, roč. 45, č. 4, s. 331-352. ISSN 01494929. 
BATES, James S. a Alan C. TAYLOR. Grandfather Involvement: Contact Frequency, Participation in Activities, and Commitment. The Journal of Men's Studies, 2003, roč. 21, č. 3, s. 305-322. ISSN 1933-0251.

BECK, Ulrich a Elisabeth BECK-GERNSHEIM. The Normal Chaos of Love. Cambridge: Polity Press, 1995. ISBN 0745613829.

BOUDINY, Kim. Active ageing: from empty rhetoric to effective policy tool. Ageing and Society, 2012, roč. 33, č. 6., s. 1077-1098. ISSN 0144686X.

BRANDTH, Berit a Elin KVANDE. Masculinity and Child Care: The Reconstruction of Fathering. The Sociological Review [online]. 1998, roč. 46, č. 2, s. 293-313 [cit. 31. 5. 2014]. DOI: 10.1111/1467954X.00120.

BURY, Mike. Ageing, gender and sociological theory. In ARBER, Sara a Jay GINN (eds.). Connecting gender and ageing: a sociological approach. Buckingham: Open University Press, 1995, s. 15-30. ISBN 0335194710.

CONNELL, Raewyn W. Masculinities. 2nd ed. Berkeley: University of California Press. 2005. ISBN 0745634273.

COX, Donald. Motives for private income transfers. Journal of Political Economy [online]. 1987, roč. 95 , č. 3, s. 508-546 [cit. 31. 5. 2014]. Dostupné z: http://www.jstor.org/stable/1831976.

CUNNINGHAM-BURLEY, Sarah. „We don't talk about it... “Issues of gender and method in the portrayal of grandfatherhood. Sociology, 1984, roč. 18, č. 3, s. 325-338. ISSN 00380385.

ČSÚ. Senioři v mezinárodním srovnání [online]. Český statistický úřad, (C) 2012 [cit. 31. 5. 2014]. Dostupné z: http://www.czso.cz/csu/2012edicniplan.nsf/publ/1417-12-n_2012.

DAVIDSON, Kate, Tom DALY a Sara ARBER. Exploring the social worlds of older men. In ARBER, Sara, Kate DAVIDSON a Jay GINN (eds.). Gender and ageing: changing roles and relationships. Buckingham: Open University Press, 2003, s. 168-185. ISBN 0335213197.

DEGNEN, Cathrine. Minding the gap: The construction of old age and oldness amongst peers. Journal of Aging Studies, 2007, roč. 21, č. 1, s. 69-80. ISSN 08904065.

DI GESSA, Giorgio, Karen F. GLASER, Debora J. PRICE, Anthea TINKER a Eloi Ribe MONTSERRAT. What Drives National Differences in Intensive Grandparental Childcare in Europe? [online]. Population Association of America, Annual Meeting Program, 2014 [cit. 31. 5. 2014]. Dostupné z: http://paa2014.princeton.edu/abstracts/140893.

DIMOVA, Ralitza a François-Charles WOLFF. Grandchild Care Transfers by Ageing Immigrants in France: Intra-household Allocation and Labour Market Implications. European Journal of Population, 2008, roč. 24, č. 3, s. 315-340. ISSN 10680-007-9122-x.

DUXBURY, Linda, Sean LYONS a Christopher HIGGINS. Too Much to do, and Not Enough Time: An Examination of Role Overload. In KORABIK, Karen, Donna S. LERO a Denise L WHITEHEAD (eds.). Handbook of Work-Family Integration: Research, Theory, and Best Practices. Burlington: Academic Press, 2008, s. 125-140. ISBN 978-0-12-372574-5.

EMSLIE, Carol, Kate HUNT a Rosaleen O'BRIEN. Masculinities in older men: A qualitative study in the West of Scotland. Journal of Men's Studies, 2004, roč. 12, č. 3, s. 207-225. ISSN 10608265.

FAIRHURST, Eileen. New identities in ageing: perspectives on age, gender and life after work. In ARBER, Sara, Kate DAVIDSON a Jay GINN (eds.). Gender and ageing: changing roles and relationships. Buckingham: Open University Press, 2003, s. 31-46. ISBN 0335213197.

FINGERMAN, Karen L. The role of offspring and in-laws in grandparents ties to their grandchildren. Journal of Family Issues, 2004 roč. 25, č. 8, s. 1026-1049.

GILLEARD, Christopher a Paul HIGGS. Cultures of Ageing. Self, Citizen and the Body. Harlow: Pearson Education, 2000. ISBN 0582356415.

GRADMAN, Theodore J. Masculine identity from work to retirement. In THOMPSON, Edward H. (ed.). Older men's lives. Thousand Oaks: SAGE, 1994, s. 104-121. ISBN 0803950802. 
GUTMAN, David. Reclaimed powers: Men and women in later life. 2nd ed. New York: Basic Books. 1994. ISBN 0-8101-1120-9

HAGESTAD, Gunhild. Parent-child relations in later life: trends and gaps in past research. In LANCASTER, Jane B., Jeanne ALTMANN, Alice S. ROSSI a Lonnie R. SHERROD (eds.). Parenting Across the Life Span. New York: Aldine de Gruyter Pubs, 1987, s. 405-429. ISBN 978-0-202-36382-0.

HANK, Karsten a Isabella BUBER. Grandparents Caring for Their Grandchildren. Findings From the 2004 Survey of Health, Ageing, and Retirement in Europe. Journal of Family Issues, 2009, roč. 30, č. 1, s. 53-73. ISSN 0192513X.

HARPER, Sarah. Grandparenthood. In JOHNSON, Malcolm L. (ed.). The Cambridge Handbook of Age and Ageing. Cambridge: Cambridge University Press, 2005, s. 422-428. ISBN 0-521-82632-2.

HASMANOVÁ MARHÁNKOVÁ, Jaroslava. Proměny prarodičovství v kontextu představ aktivního stáří. In RYŠAVÝ, Dan. Sociologica-Andragogica. Problémy ohrožených skupin. Mezigeneračni vztahy v rodině, 2010, s. 11-26. ISSN 1803-0246.

HASMANOVÁ MARHÁNKOVÁ, Jaroslava. Aktivita jako projekt: Diskurz aktivního stárnutí a jeho odezvy v životech českých seniorů a seniorek. Praha: Sociologické nakladatelství, 2013. ISBN 978-80-7419-152-7.

HIGGS, Paul, Miranda LEONTOWITSCH, Fiona STEVENSON a Ian Rees JONES. Not just old and sick - the „will to health“ in later life. Ageing and Society, 2009, roč. 29, č. 5, s. 687-707. ISSN 0144686X.

CHERLIN, Andrew J. a Frank F. FURSTENBERG, Jr. The new american grandparent. 2nd ed. Cambridge: Harvard University Press, 1986. ISBN 9780674029484.

IGEL, Corinne, Martina BRANDT, Klaus HABERKERN a Marc SZYDLIK. Specialization between Family and State: Intergenerational Time Transfers in Western Europe. Journal of Comparative Family Studies, 2009, roč. 40, č. 2, s. 203-226. ISSN 00472328.

IGEL, Corinne a Marc SZYDLIK. Grandchild care and welfare state arrangements in Europe. Journal of European Social Policy, 2011, roč. 21, č. 3, s. 210-224. ISSN 0958-9287.

JONES, Ian Rees, Martin HYDE, Christina R. VICTOR, Richard D. WIGGINS, Chris GILLEARD a Paul HIGGS. The evolution of the third age. In JONES, Ian R., Martin HYDE, Christina R. VICTOR, Richard D. WIGGINS, Chris GILLEARD a Paul HIGGS (eds.). Ageing in a Consumer Society. From Passive to Active Consumption in Britain. Bristol: Bristol Polity Press, 2008, s. 13-29. ISBN 1861348827.

JONES, Rebecca L. „Older people“ talking as if they were not older people: Positioning theory as an explanation. Journal of Ageing Studies, 2006, č. 20, s. 79-91. ISSN 08904065.

KATZ, Stephen. Busy Bodies: Activity, Ageing and the Management of the Everyday Life. Journal of Ageing Studies, 2000, roč. 14, č. 2, s. 135-152. ISSN 08904065.

KOHLI, Martin. Private and Public Transfers Between Generations: Linking the Family and the State. European Societies. 1998, roč. 1, č. 1, s. 81-104. ISSN 1461-6696.

KUCHAŘOVÁ, Věra, Ladislav RABUŠIC a Lucie EHRENBERGEROVÁ. Život ve stárí. Zpráva o výsledcich empirického šetření. Praha: VÚPSV, Socioklub, 2002.

LASLETT, Peter. The Fresh Map of Life: The Emergence of the Third Age. 2nd ed. London: Weidenfeld and Nicolson, 1991. ISBN 0-674-32327-0.

MALTER, Frederic a Axel BÖRSCH-SUPAN (eds.). SHARE Wave 4: Innovations \& Methodology. München: Munich Center for the Economics of Aging, 2013. ISBN 9783000408021.

MANN, Robin. Out of the shadows? Grandfatherhood, age and masculinities. Journal of Aging Studies, 2007, roč. 21, č. 4, s. 281-291. ISSN 0890-4065.

MANN, Robin a George LEESON. Grandfathers in Contemporary Families in Britain: Evidence from Qualitative Research. Journal of Intergenerational Relationships, 2010, roč. 8, č. 3, s. 234-248. ISSN 15350770. 
MANN, Robin, Hafiz T. A. KHAN a George W. LEESON. Age and gender differences in grandchildren 's relations with their maternal grandfathers and grandmothers [online]. Oxford Institute of Ageing, 2009 [cit. 22. 5. 2014]. Dostupné z: http://www.ageing.ox.ac.uk/system/files/Workingpaper209.pdf.

MARSHALL, Barbara L. a Stephen KATZ. From androgyny to androgens: Resexing the ageing body. In CALASANTI, Toni M. a Kathleen F. SLEVIN (eds.). Age Matters. New York: Routledge, 2006, s. 75-99. ISSN 0-415-95223-9.

McGARRY, Kathleen a Robert F. SCHOENI. Transfer Behavior Within the Family: Results From the Asset and Health Dynamics Study. The Journals of Gerontology, 1997, č. 52B, s. 85-92. ISSN 10795014.

MEYER, Madonna H. Grandmothers at Work: Juggling Families and Jobs. New York: New York University Press, 2014. ISBN 978-0-8147-2947-2.

MILLWARD, Christine. Effects of Gender and Paid Work on Grandparenting Family. Family Matters, 1997, č. 46, s. 18-21. ISSN 9707091389.

MILLWARD, Christine. Family relationships and intergenerational exchange in later life. [online]. Melbourne: Australian Institute of Family Studies, 1998 [cit. 31. 5. 2014]. ISBN 0642320535. Dostupné z: http://aifs.gov.au/institute/pubs/WP15.pdf

MOODY, Harry R. Productive Aging and the ideology of Old Age. In MORROW-HOWELL, Nancy, James HINTERLONG a Michael Wayne SHERRADEN (eds.). Productive Aging. Baltimore: Johns Hopkins University Press, 2001, s. 175-194. ISBN 0-8018-6557-3.

NEUGARTEN, Bernice L. a Karol K. WEINSTEIN. The Changing American Grandparent. Journal of Marriage and Family, 1964, roč. 26, č. 2, s. 199-204. ISSN 00222445.

PHILLIPSON, Chris a Jason L. POWELL. Risk, social welfare and old age. In TULLE, Emanuelle (ed.). Old age and agency. New York: Nova Science Publishers, 2004, s. 17-26. ISBN 1-59033-884-7.

REITZES, Donald C. a Elizabeth J. MUTRAN. Grandparent Identity, Intergenerational Family Identity, and Well-Being. The Journals of Gerontology, 2004, roč. 59, č. 4, s. 213-219. ISSN 10795014.

ROBERTO, Karen A., Katherine R. ALLEN a Rosemary BLIESZNER. Grandfathers' perceptions and expectations of relationships with their adult grandchildren. Journal of Family Issues, 2001, roč. 22, č. 4, s. 407-426. ISSN 0192513X.

ROWE, John W. a Robert L. KAHN. Successful aging. New York: Pantheon Books, 1998. ISBN 0440508630 .

RUBINSTEIN, Robert L. The third age. In WEISS, Robert S. a Scott A. BASS (eds.). Challenges of the Third Age. Oxford: Oxford University Press, 2002, s. 29-41. ISBN 9780195150254.

SILVER, Catherine B. Gendered Identities in Old Age: Toward (de)gendering. Journal of Aging Studies, 2003, roč. 17, č. 4, s. 379-397. ISSN 08904065.

SILVERSTEIN, Merril, Daphna GANS a Frances M. YANG. Intergenerational support to aging parents. The role of norms and needs. Journal of Family Issues, 2006 roč. 27, č. 8, s. 1068-1084. ISSN 0192513X.

SOMARY, Karen a George STRICKER. Becoming a grandparent: A longitudinal study of expectations and early experiences as a function of sex and lineage. The Gerontologist, 1998, roč. 38, č. 1, s. 53-61. ISSN 00169013.

SPITZE, Glenna a John LOGAN Gender differences in family support. Is there a payoff? The Gerontologist, 1989, roč. 29, č. 1, s. 108-113. ISSN 00169013.

SÝKOROVÁ, Dana. Autonomie ve stáři. Kapitoly z gerontosociologie. Praha: Sociologické nakladatelství, 2007. ISBN 9788086429625.

TARRANT, Anna. Constructing a social geografy of grandparenthood: a new focus for intergenerationality. Area, 2010, roč. 42, č. 2, s. 190-197. ISSN 00040894. 
TARRANT, Anna. Grandfathering: the construction of new identities and masculinities. In ARBER, Sara a Virpi TIMONEN (eds.). Contemporary Grandparenting: Changing Family Relationships in Global Contexts. Bristol: Policy Press, 2012, s. 200-222. ISBN 978184742.9674.

THOMPSON, Edward H. Jr. a Patrick M. WHEARTY. Older Men's Social Participation: The Importance of Masculinity Ideology. The Journal of Men's Studies, 2004, roč. 13, č. 1, s. 5-24. ISSN 10608265.

UHLENBERG, Peter. Historical Forces Shaping Grandparent-Grandchild Relationships: Demography and Beyond. Annual Review of Gerontology and Geriatrics, 2005, roč. 24, s. 77-98. ISSN 01988794.

UHLENBERG, Peter a Bradley G. HAMMILL. 1998. Frequency of Grandparent Contact With Grandchild Sets: Six Factors That Make a Difference. The Gerontologist, 1998, roč. 38, č. 3, s. 276-285. ISSN 00169013.

VANDELL, Deborah L., Kathleen McCARTNEY, Margaret T. OWEN, Cathryn BOOTH a Alison CLARKE-STEWART. Variations in Child Care by Grandparents During the First Three Years. Journal of Marriage and Family, 2003, roč. 65, č. 2, s. 375-381. ISSN 00222445.

VERBRUGGE, Lois M. a Angelique CHAN. Giving help in return: Family reciprocity by older Singaporeans. Ageing and Society, 2008, roč. 28, č. 1, s. 5-34. ISSN 0144686X.

VIDOVIĆOVÁ, Lucie a Ladislav RABUŠIC. Senioři a sociální opatření v oblasti stárnutí v pohledu české veřejnosti. Zpráva z empirického výzkumu [online]. Výzkumný ústav práce a sociálních věcí, 2003 [cit. 31. 5. 2014]. Dostupné z: http://www.mature-project.eu/materials/vidrab.pdf.

WALDROP, Deborah P. a Joseph A. WEBER. From grandparent to caregiver: The stress and satisfaction of raising grandchildren. Families in Society, 2001, roč. 82, č. 5, s. 467-472. ISSN 10443894.

WEISS, Robert S. a Scott A. BASS. Introduction. In WEISS, Robert S. a Scott A. BASS (eds.). Challenges of the Third Age, 2002. Oxford: Oxford University Press, 2002, s. 3-13. ISBN 9780195150254.

WILTON, Virginia a Judith A. DAVEY. Grandfathers - their changing family roles and contributions [online]. Wellington: New Zealand Institute for Research on Ageing Victoria University of Wellington, 2006 [cit. 31. 5. 2014]. Dostupné z: http://www.familiescommission.org.nz/sites/default/files/ downloads/BS-grandfathers.pdf.

\section{Autorka}

Nela Patschová studuje magisterský program sociologie na Masarykově univerzitě v Brně. Zaměřuje se na témata spojená se stárnutím, bezdětností a spokojeností seniorů, prarodičovstvím a mezigeneračními výměnami.

Kontakt: 386253@mail.muni.cz 